\title{
NALLD Business
}

California-Nevada Chapter: The California-Nevada Chapter of NALLD met on October 31, 1970 at the University of the Pacific in Stockton. Speakers for the meeting were Dr. Jesse Sawyer, Mr. Jonathon Tibbets and Mr. Roy Krynitz. The following committee members were elected:

Chairman: Mr. Yusuke Kawarabayashi, University of the Pacific

Vice-Chairman: Mr. Jonathan Tibbets, University of California at Irvine, Irvine, California

Secretary: Mrs. Margaret Hagner, University of Nevada, Reno, Nevada

Treasurer: Mr. Christian Philippon, University of California at Berkeley, Berkeley, California

Commercial Rep: Mr. Morton Hague, Morton Laboratory, Oakland, California

Foreign Language Media Symposium: The University of WisconsinParkside was the site of a foreign language media conference on October 17, 1970. The conference was well attended and lively discussions followed the presentations made by the speakers and panelists. Mr. Harry Walbruck, University of Wisconsin-Parkside, was the presiding officer for the symposium.

Reports of Meetings: NALLD members attending local meetings concerning language labs are encouraged to submit reports of these meetings to the NALLD Journal.

Tape Market: Many lab directors and their schools are faced with the problem of what to do with the master tapes for texts which are no longer used by their school. They can either erase and re-bulk the 


\section{NALLD Business}

tapes or store them to gather dust. We offer another solution. We will list in the NALLD Journal tapes for sale by schools. Only those sold by the publisher to the school and in their original package will be listed. The following should be observed:

1. Use this form: Language, Title, Author, Editor, Year, Number of reels, number of tracks, cost, selling price (we suggest $50 \%$ discount), person to contact.

2. NALLD and the NALLD Journal accept no responsibility for the transportation between buyer and seller. The quality of the tapes and the method of payment for them should be a matter established between buyer and seller before the transaction is made.

3. The listings in the Journal will be determined by the space available. The NALLD Journal reserves the right to select listings.

\section{GERMAN}

"TOWARD FLUENCY IN SPEAKING AND WRITING GERMAN" - Erich Hofacker, Charles Scribners and Sons, 1963, 7 reels, dual track, \$15. CONTACT: Walter Davison, Language Lab, University of Pittsburgh, Thackeray and O'Hara Streets, Pittsburgh, Pa. 15213.

"FOUNDATION COURSE IN GERMAN" - Homberger and Ebelke, Heath, 1960, 9 reels, dual track. CONTACT: Walter Davison, Language Lab, University of Pittsburgh, Thackeray and O'Hara Streets, Pittsburgh, Pa. 15213.

"GERMAN FOR BEGINNERS," 2nd edition - Cunz, Groenke, Vail, Ronald Press, 1965, 10 reels, dual track. CONTACT: Walter Davison, Language Lab, University of Pittsburgh, Thackeray and O'Hara Streets, Pittsburgh, $\mathrm{Pa} .15213$.

\section{FRENCH}

"BASIC CONVERSATIONAL FRENCH," 3rd Edition - Harris and Leveque, recorded at $33 / 4$, double track, 17 reels. CONTACT: Gilles E. Auger, A-V Director, A-V Department, Nasson College, Springvale, Me. 04083.

"BASIC CONVERSATIONAL FRENCH," 3rd edition - Harris and Leveque, Holt-Rinehart, Winston, 1962, 17 reels, dual track. CONTACT: Walter Davison, Language Lab, University of Pittsburgh, Thackeray and O'Hara Streets, Pittsburgh, Pa. 15213. 
BRIEF ORAL FRENCH REVIEW," 3rd edition - Karl G. Bottke, Appleton-Century-Croft, 1964, 4 reels, dual track. CONTACT: Walter Davison, Language Lab, University of Pittsburgh, Thackeray and O'Hara Streets, Pittsburgh, Pa. 15213.

"FRENCH FOR REVIEW" - Heise, Edward, recorded at $33 / 4$, full track, 3 reels. CONTACT: Gilles E. Auger, A-V Director, A-V Department, Nasson College, Springvale, Me. 04083.

"FRENCH - LEVEL THREE. A-LM" - Harcourt, Brace and World, 1964, 6 records. CONTACT: Walter Davison, Language Lab, University of Pittsburgh, Thackeray and O'Hara Streets, Pittsburgh, Pa. 15213.

"INTERMEDIATE CONVERSATIONAL FRENCH" - Harris and Leveque, recorded at $33 / 4$, double track, 8 reels. CONTACT: Gilles E. Auger, A-V Director, A-V Department, Nasson College, Springvale, Me. 04083.

\section{SPANISH}

"CONTINUING SPANISH I, MLA" - American Book Co., 1967, 7 reels, 5 dual track and 2 full track. CONTACT: Walter Davison, Language Lab, University of Pittsburgh, Thackeray and O'Hara Streets, Pittsburgh, Pa. 15213.

The University of the Pacific Language Laboratory in Stockton, California has a high speed copier, 3 years old, which was purchased at $\$ 2,000$. The lab would like to sell it for $\$ 700$. Anyone interested please contact Mr. Yusuke Kawarabayashi

Director, Language Laboratory

University of the Pacific

Stockton, California 95204. 